\title{
Yield performance of Boro rice in response to urea super granular (USG)
}

\author{
M. H. Bony, S. K. Paul ${ }^{\star}$, M. A. Kaderand and M. A. R. Sarkar \\ Department of Agronomy, Bangladesh Agricultural University, Mymensingh-2202, Bangladesh \\ *Email: skpaull@gmail.com
}

\begin{abstract}
The experiment was conducted during December 2012 to June 2013 in the farmer's field adjacent to Bangladesh Agricultural University (BAU), a village named Boira under Sadar Upazilla of Mymensingh to study the yield performance of Boro rice in response to USG. The experiment comprised two rice varieties viz. Binadhan-5 and BRRI dhan29 and seven levels of USG viz.i) prilled urea (PU) $280 \mathrm{~kg} \mathrm{ha}^{-1}$ (control),ii)USG $1.8 \mathrm{~g} / 4$ hills in every alternate row applied at $5 \mathrm{~cm}$ depth, iii) USG $1.8 \mathrm{~g} / 4$ hills in every alternate row applied at $10 \mathrm{~cm}$ depth, iv) USG $2.7 \mathrm{~g} / 4$ hills in every alternate row applied at $5 \mathrm{~cm}$ depth, v)USG $2.7 \mathrm{~g} / 4$ hills in every alternate row applied at $10 \mathrm{~cm}$ depth, vi) USG 3.6g/4 hills in every alternate row applied at $5 \mathrm{~cm}$ depth and vii)USG $3.6 \mathrm{~g} / 4$ hills in every alternate row applied at $10 \mathrm{~cm}$ depth. The experiment was laid out in a randomized complete block design with three replications. Variety, level of USG and their interaction exerted significant influence on yield contributing characters and yield of Boro rice. BRRI dhan29 produced higher number of effective tillers hill ${ }^{-1}$ and heaviest grain than that of Binadhan-5. As a result of superior yield parameters, BRRI dhan29 gave higher yield $\left(7.67 \mathrm{t} \mathrm{ha}^{-1}\right)$ than Binadhan-5 $\left.(6.52 \mathrm{t} \mathrm{ha})^{-1}\right)$. In case of USG, the highest number of total tillers hill $^{-1}$, grains panicle ${ }^{-1}, 1000$-grain weight and grain yield $\left(7.59 \mathrm{t}^{-1}\right)$ were obtained $^{-1}$ from USG @ 3.6g/4 hills in every alternate row applied at $5 \mathrm{~cm}$ depth. The lowest values of all the parameters were obtained from PU. Considering their interaction effect, BRRI dhan29 with USG 3.6g/4 hills in every alternate row applied at $5 \mathrm{~cm}$ depth produced best yield attributes, grain $\left(8.38 \mathrm{t} \mathrm{ha}^{-1}\right)$ and straw yield $\left(9.26 \mathrm{t} \mathrm{ha}^{-1}\right)$. The lowest performance was observed in Binadhan-5 with PU. The overall results suggest that farmers can be advised to cultivate BRRI dhan29 fertilized with USG $3.6 \mathrm{~g} / 4$ hills in every alternate row at $5 \mathrm{~cm}$ depth for getting highest yield in Boro season under the agro-climate condition of the study area.
\end{abstract}

Keywords: Bororice, Yield, USG

\section{Introduction}

Bangladesh is favourable for rice cultivation throughout the year, but the unit area yield is much below to those of other leading rice growing countries of the world. Emphasis should be given to increase the yield of rice (specially Boro rice) through adaptation of intensive fertilizer management along with other improved technology. Plant nutrients are essential for cultivation of crops. Among the nutrients, $\mathrm{N}$ is the most important and key input for rice production all over the world for its large requirements and instability in soil. After the primary input seed i.e., crop variety, $\mathrm{N}$ fertilizer is one of the major input for crop production that can contribute a lot for higher rice yield. Total $\mathrm{N}$ uptake by rice plant per unit area varies among rice varieties. $\mathrm{N}$ is required in adequate amount at early, at midtillering and panicle initiation stage for better grain development. It is a fact that rice plants require more nutrients to produce more yield. The efficiency of $\mathrm{N}$ fertilizer especially urea is very low in rice though urea is the principal source of nitrogen for rice in Bangladesh agriculture. This important element has been found to be deficit in most agricultural soils of Bangladesh. However, the nature and magnitude of $\mathrm{N}$ loss largely depends upon the sources of $\mathrm{N}$ fertilizer and methods of $\mathrm{N}$ fertilizer application. Prilled urea (PU) is the most commonly used $\mathrm{N}$ fertilizer for rice cultivation in Bangladesh. Unfortunately, the efficiency of PU in rice culture is only 25-30 per cent and rest $70-75 \%$ is lost for many reasons after application (BRRI, 2008). On the other hand, USG can save $30 \%$ more $\mathrm{N}$ than that of $\mathrm{PU}$, increase absorption rate, improve soil health and ultimately increase the rice yield (Savant et al. 1991). Placement of USG in the root zone is another most effective method for increasing the $\mathrm{N}$ use efficiency (NUE) and rice yield (Sharma, 1985). The loss of nitrogen can considerably be reduced by deep placement of USG. USG stops denitrification process and minimizes urea concentration in irrigation water. As a result, it reduces $\mathrm{N}$ loss and improves its use efficiency by $20-$ 25\% (Craswell and De Datta, 1980 and Pillai, 1981). The present study was, therefore, undertaken to determine the optimum dose of USG with depth of placement for maximizing yield and yield attributes of two Boro rice varieties. 


\section{Materials and Methods}

The experiment was carried out in the farmer's field adjacent to BAU, a village named Boira, Sadar Upazilla of Mymensingh under University-Community Bridging project funded by British Council during December 2012 to June 2013 to study the yield performance of Binadhan-5 and BRRI dhan29 during Boro season under different levels of USG applied at various depth of placement. The experiment consisted of two rice varieties viz Binadhan-5 and BRRI dhan29 and seven levels of USG viz. (i) prilled urea $280 \mathrm{~kg} \mathrm{ha}^{-1}$, (ii) USG $1.8 \mathrm{~g} / 4$ hills in every alternate row applied at $5 \mathrm{~cm}$ depth, (iii) USG $1.8 \mathrm{~g} / 4$ hills in every alternate row applied at $10 \mathrm{~cm}$ depth, (iv) USG $2.7 \mathrm{~g} / 4$ hills in every alternate row applied at $5 \mathrm{~cm}$ depth, (v) USG $2.7 \mathrm{~g} / 4$ hills in every alternate row applied at $10 \mathrm{~cm}$ depth, (vi) USG $3.6 \mathrm{~g} / 4$ hills in every alternate row applied at $5 \mathrm{~cm}$ depth, (vii) USG $3.6 \mathrm{~g} / 4$ hills in every alternate row applied at $10 \mathrm{~cm}$ depth. The experiment was laid out in a randomized complete block design (RCBD) with three replications. Each replication represented a block and each block was divided into 14 unit plots. Total number of unit plot was 42. The size of unit plot was $4.0 \mathrm{~m} \times 2.5 \mathrm{~m}$. The distance between blocks and plots were $1 \mathrm{~m}$ and $0.75 \mathrm{~m}$, respectively. Seeds of Binadhan -5 and BRRI dhan 29 were collected from BADC Seed Production Farm, Mymensingh. The seeds were sprouted by soaking in water for 48 hours and seedlings were raised in wet nursery bed. Thirty five-day old seedlings were uprooted from the seedbed very carefully and were transplanted in the experimental plots on 2 February, 2013. High border around the each plot was maintained to control water movement. Intercultural operations were done as and when necessary. Harvesting was done when $90 \%$ of the grains became golden (Binadhan-5) and golden yellow (BRRI dhan29) in color. BRRI dhan29 was harvested on 21 May, 2013 and Binadhan-5 on 13 May 2013. Whole plots were harvested to record the data on grain and straw yields. Prior to harvest, five hills (excluding border hills) were selected randomly from each plot to record the data on yield contributing characters. After recording data, the grains and straws from five sampling hills were added to the total grain and straw yields of respective plots. Data on different parameters were compiled and tabulated in proper form for statistical analysis. The mean differences among the treatments were adjudged by Duncan's Multiple Range Test (Gomez and Gomez, 1984).

\section{Results and Discussion}

\section{Varietal performance}

Yield contributing characters and yield of Boro rice were significantly affected by variety (Table 1). Binadhan-5 produced taller plant $(112.4 \mathrm{~cm})$ compared to that of BRRI dhan29 $(97.37 \mathrm{~cm})$. These differences are mostly due to the genetic variation among the varieties. These results were consistent to those of Khisha (2002) and Rahman (2003), who recorded variable plant height among the varieties. Higher number of total tillers hill ${ }^{-1}(16.16)$ was found in BRRI dhan29 and the lower one (14.33) was counted in Binadhan-5. Similar results were reported elsewhere (Nuruzzaman et al. 2000; Tyebet al. 2013 and Islam et al. 2014). BRRI dhan29produced higher number of effective tillers hill ${ }^{-1}$ (14.00), total spikelets panicle $^{-1}$ (184.0), grains panicle ${ }^{-1}$ (170.7), 1000-grain weight $(25.32$ g)and lower number of effective tillers hill ${ }^{-1}(11.91)$, total spikelets panicle ${ }^{-1}$ (169.2), grains panicle ${ }^{-1}$ (153.6), 1000-grain weight $(24.65 \mathrm{~g})$ was produced by the variety Binadhan-5. BRRI dhan29 gave the higher grain yield $\left(7.671 \mathrm{t} \mathrm{ha}^{-1}\right)$ and straw yield (8.66 t ha-1) compared to Binadhan-5.Varietal differences regarding grain yield was reported elsewhere (Khisha, 2002; Tyebet al. 2013 and Islam et al. 2014).

\section{Effect of level of USG}

Plant height, yield contributing characters and yield of Boro rice were significantly affected by different levels of USG (Table 2). The plant height ranged from $102.2 \mathrm{~cm}$ to $106.2 \mathrm{~cm}$. The highest plant height $(106.2 \mathrm{~cm})$ was recorded when USG $3.6 \mathrm{~g} / 4$ hills was applied in every alternate row with $5 \mathrm{~cm}$ depth of placement and lowest plant height $(102.2 \mathrm{~cm})$ was recorded when fertilized with PU @ $280 \mathrm{~kg} \mathrm{ha}^{-1}$. The highest number of total tillers hill ${ }^{-1}(16.10)$ was produced when USG was applied $3.6 \mathrm{~g} / 4$ hills in every alternate row applied at $10 \mathrm{~cm}$ depth of placement. The lowest number of total tillers hill $^{-1}(13.93)$ was recorded when PU $280 \mathrm{~kg} \mathrm{ha}^{-1}$ was applied. The number of total tillers hill ${ }^{-1}$ was increased as the USG 
level increased. Total tillers hill ${ }^{-1}$ was positively correlated with applied $\mathrm{N}$ as reported by Singh and Shivay (2003) and BRRI (2000). The highest number of effective tillers hill ${ }^{-1}(14.07)$,total spikelets panicle ${ }^{-1}$ (183.0), grains panicle ${ }^{-1}(170.0), 1000$-grains (25.31g)was produced when USG @ 3.6g/4 hills in every alternate row applied at $5 \mathrm{~cm}$ depth of placement performed and the lowest number of effective tillers hill ${ }^{-1}$ (11.43), total spikelets panicle ${ }^{-1}$ (168.8), grains panicle ${ }^{-1}(152.7), 1000$-grains (24.56g) was obtained when PU $280 \mathrm{~kg} \mathrm{ha}^{-1}$ was applied. Thakur (1999) reported that the number of grains panicle ${ }^{-1}$ increased significantly with increments in levels of USG. Baligar and Ganin (2001) who reported that the weight of 1000-grain increased significantly and quardratically with increasing USG levels. The grain yield $(7.59 \mathrm{t}$ $\mathrm{ha}^{-1}$ ) and straw yield $\left(8.49 \mathrm{t} \mathrm{ha}^{-1}\right)$ were the highest with the application of USG $3.6 \mathrm{~g} / 4$ hills in every alternate row applied at $5 \mathrm{~cm}$ depth of placement and the lowest grain yield $\left(5.32 \mathrm{t} \mathrm{ha}^{-1}\right)$ and straw yield ( $7.13 \mathrm{t} \mathrm{ha}^{-1}$ ) were obtained from PU applied at $280 \mathrm{~kg} \mathrm{ha}^{-1}$. Due to application of different level of USG, grain yield increased from $28.95 \%$ to $42.67 \%$ over PU. Placement of USG in root zone increased grain yield was reported elsewhere (Sharma, 1985 and Savant et al. 1991). The highest harvest index (47.19 $\%$ ) was recorded from USG $2.7 \mathrm{~g} / 4$ hills in every alternate row with $10 \mathrm{~cm}$ depth of placement and the lowest one (42.73\%) was obtained when PU was applied. Hasan (2007) reported that harvest index increased with increasing USG up to a certain level and then decreased.

Table 1. Effect of variety on the yield contributing characters and yield of Boro rice

\begin{tabular}{|c|c|c|c|c|c|c|c|c|c|}
\hline Variety & $\begin{array}{c}\text { Plant } \\
\text { height } \\
(\mathrm{cm})\end{array}$ & $\begin{array}{c}\text { Total } \\
\text { Tillers } \\
\text { hill }^{-1} \text { (No.) } \\
\end{array}$ & $\begin{array}{l}\text { Effective } \\
\text { tillers hill } \\
\text { (No.) }\end{array}$ & $\begin{array}{c}\text { Total spikelets } \\
\text { panicle }{ }^{-1} \\
\text { (No.) }\end{array}$ & $\begin{array}{c}\text { Grains } \\
\text { panicle }^{-1} \\
\text { (No.) }\end{array}$ & $\begin{array}{c}\text { 1000-grain } \\
\text { weight } \\
\text { (g) }\end{array}$ & $\begin{array}{l}\text { Grain } \\
\text { yield } \\
\left(\mathrm{t} \mathrm{ha}^{-1}\right)\end{array}$ & $\begin{array}{c}\text { Straw } \\
\text { yield } \\
\left(\mathrm{t} \mathrm{ha}^{-1}\right)\end{array}$ & $\begin{array}{c}\text { Harvest } \\
\text { index } \\
(\%) \\
\end{array}$ \\
\hline Binadhan-5 & $112.4 \mathrm{a}$ & $14.33 \mathrm{~b}$ & $11.91 \mathrm{~b}$ & $169.2 \mathrm{~b}$ & $153.6 \mathrm{~b}$ & $24.65 b$ & $6.52 \mathrm{~b}$ & $7.43 b$ & 46.74 \\
\hline BRRI dhan29 & $97.37 b$ & $16.16 a$ & $14.00 \mathrm{a}$ & $184.0 \mathrm{a}$ & $170.7 a$ & $25.32 a$ & $7.67 a$ & $8.66 a$ & 46.96 \\
\hline $\mathrm{LSD}_{0.05}$ & 0.694 & 0.259 & 0.280 & 2.32 & 2.45 & 0.195 & 0.170 & 0.178 & - \\
\hline Level of sig. & $\star \star *$ & $\star \star$ & $\star * *$ & $\star \star *$ & ** & ** & $\star \star *$ & $\star *$ & NS \\
\hline
\end{tabular}

In a column, figures having dissimilar letter(s) differ significantly as per DMRT $* *=$ Significant at $1 \%$ level of probability

NS $=$ Not significant

Table 2. Effect of level of USG on the yield contributing characters and yield of Boro rice

\begin{tabular}{|c|c|c|c|c|c|c|c|c|c|c|}
\hline $\begin{array}{c}\text { Urea } \\
\text { doses }\end{array}$ & $\begin{array}{l}\text { Plant } \\
\text { height } \\
(\mathrm{cm})\end{array}$ & $\begin{array}{c}\text { Total } \\
\text { tillers } \\
\text { hill }^{-1} \text { (No.) }\end{array}$ & $\begin{array}{l}\text { Effective } \\
\text { tillers } \\
\text { hill }^{-1} \text { (No.) }\end{array}$ & $\begin{array}{c}\text { Total } \\
\text { spikelets } \\
\text { panicle }^{-1} \text { (No.) }\end{array}$ & $\begin{array}{c}\text { Grains } \\
\text { panicle }{ }^{-1} \\
\text { (No.) }\end{array}$ & $\begin{array}{c}\text { 1000-grain } \\
\text { weight } \\
\text { (g) }\end{array}$ & $\begin{array}{l}\text { Grain } \\
\text { yield } \\
\left(\mathrm{t} \mathrm{ha}^{-1}\right)\end{array}$ & $\begin{array}{l}\text { Straw } \\
\text { yield } \\
\left(\mathrm{t} \mathrm{ha}^{-1}\right)\end{array}$ & $\begin{array}{l}\text { Harvest } \\
\text { index } \\
(\%)\end{array}$ & $\begin{array}{c}\text { Yield (\%) } \\
\text { increase over } \\
\text { control (PU) }\end{array}$ \\
\hline $\mathrm{U}_{0}$ & $102.2 \mathrm{c}$ & $13.93 d$ & $11.43 \mathrm{e}$ & $168.8 \mathrm{c}$ & $152.7 \mathrm{c}$ & $24.56 c$ & $5.32 d$ & $7.13 d$ & $42.73 c$ & - \\
\hline $\mathrm{U}_{1}$ & $104.4 \mathrm{~b}$ & $14.43 \mathrm{c}$ & $11.99 \mathrm{~d}$ & $170.7 \mathrm{c}$ & $155.0 \mathrm{c}$ & $24.70 c$ & $6.86 \mathrm{c}$ & $7.79 \mathrm{c}$ & $46.75 a$ & 28.95 \\
\hline $\mathrm{U}_{2}$ & 105.0ab & $15.56 \mathrm{~b}$ & $13.12 b$ & $175.4 b$ & $161.6 \mathrm{~b}$ & $24.87 c$ & $6.94 \mathrm{c}$ & $8.22 a b$ & $45.89 b$ & 30.45 \\
\hline $\mathrm{U}_{3}$ & $105.4 a b$ & $14.70 \mathrm{c}$ & $12.55 \mathrm{c}$ & $175.6 \mathrm{~b}$ & $159.9 b$ & $24.91 b c$ & $7.12 \mathrm{bc}$ & $8.00 \mathrm{bc}$ & $47.06 a$ & 33.83 \\
\hline $\mathrm{U}_{4}$ & 105.3ab & $16.07 a$ & $13.89 a$ & $180.2 a$ & $166.4 \mathrm{a}$ & $25.27 a b$ & 7.39ab & $8.26 a b$ & $47.19 a$ & 38.91 \\
\hline$U_{5}$ & $106.2 \mathrm{a}$ & $15.95 a b$ & $14.07 a$ & $183.0 \mathrm{a}$ & $170.0 \mathrm{a}$ & $25.31 a$ & $7.59 a$ & $8.49 a$ & $47.14 a$ & 42.67 \\
\hline $\mathrm{U}_{6}$ & 105.8ab & $16.10 a$ & $13.65 a$ & $182.6 a$ & $169.6 \mathrm{a}$ & $25.27 a b$ & $7.47 a$ & $8.43 a$ & $46.93 a$ & 40.41 \\
\hline $\mathrm{LSD}_{0.05}$ & 1.30 & 0.485 & 0.524 & 4.34 & 4.59 & 0.365 & 0.318 & 0.333 & 0.712 & - \\
\hline $\begin{array}{l}\text { Level of } \\
\text { sig. }\end{array}$ & ** & ** & ** & ** & ** & ** & ** & ** & ** & - \\
\hline CV (\%) & 1.05 & 2.68 & 3.41 & 2.07 & 2.39 & 1.23 & 3.77 & 3.50 & 1.28 & - \\
\hline
\end{tabular}

In a column, figures having dissimilar letter(s) differ significantly as per DMRT

** = Significant at $1 \%$ level of probability,

$\mathrm{U}_{0}=$ Prilled urea $280 \mathrm{~kg} \mathrm{ha}^{-1}$,

$\mathrm{U}_{1}=$ USG $1.8 \mathrm{~g} / 4$ hills of alternate row applied at $5 \mathrm{~cm}$ depth,

$\mathrm{U}_{2}=\mathrm{USG} 1.8 \mathrm{~g} / 4$ hills of alternate row applied at $10 \mathrm{~cm}$ depth,

$\mathrm{U}_{3}=$ USG $2.7 \mathrm{~g} / 4$ hills of alternate row applied at $5 \mathrm{~cm}$ depth,

$\mathrm{U}_{4}=$ USG $2.7 \mathrm{~g} / 4$ hills of alternate row applied at $10 \mathrm{~cm}$ depth,

$\mathrm{U}_{5}=$ USG $3.6 \mathrm{~g} / 4$ hills of alternate row applied at $5 \mathrm{~cm}$ depth,

$\mathrm{U}_{6}=\mathrm{USG} 3.6 \mathrm{~g} / 4$ hills of alternate row applied at $10 \mathrm{~cm}$ depth. 


\section{Interaction effect of variety and level of USG}

Interaction of variety and level of USG showed significant influence on yield contributing characters and yield of Boro rice. Interaction between BRRI dhan29 and USG 3.6g/4 hills in every alternate row applied at $5 \mathrm{~cm}$ depth of placement produced the highest number of total tillers hill ${ }^{-1}$ (17.03), effective tillers hill $^{-1}$ (15.46), grainspanicle ${ }^{-1}(184.0)$ and the lowest number of total tillers hill ${ }^{-1}(13.02)$, effective tillers hill ${ }^{-1}$ (10.48), grainspanicle ${ }^{-1}$ (145.0)were obtained due to the interaction of Binadhan-5 and $280 \mathrm{~kg} \mathrm{ha}^{-1}$ as PU. Interaction between BRRI dhan29 and USG $3.6 \mathrm{~g} / 4$ hills in every alternate row applied at $5 \mathrm{~cm}$ depth of placement was found to be the best in respect of number of total spikelets panicle ${ }^{-1}(194.0)$ and the lowest number of total spikelets panicle ${ }^{-1}(162.1)$ was obtained from the interaction between Binadhan-5 and PU @ $280 \mathrm{~kg} \mathrm{ha}^{-1}$. The highest grain yield $\left(8.38 \mathrm{t} \mathrm{ha}^{-1}\right)$, straw yield $\left(9.26 \mathrm{t} \mathrm{ha}^{-1}\right)$ and harvest index (47.51\%)was recorded in the treatment combination of BRRI dhan29 fertilized with USG $3.6 \mathrm{~g} / 4$ hills in every alternate row applied at $5 \mathrm{~cm}$ depth of placement and the lowest grain yield $\left(5.92 \mathrm{t} \mathrm{ha}^{-1}\right)$ and straw yield (6.81 tha ${ }^{-1}$ ) were found in the treatment combination of Binadhan-5 fertilized with PU @ $280 \mathrm{~kg} \mathrm{ha}^{-1}$. The lowest harvest index (44.63) was obtained in the combination of BRRI dhan29 with USG $1.8 \mathrm{~g} / 4$ hills in every alternate row applied at $10 \mathrm{~cm}$ depth.

Table 3. Effect of interaction of variety and level of USG on the yield contributing characters and yield of Boro rice

\begin{tabular}{|c|c|c|c|c|c|c|c|c|c|}
\hline $\begin{array}{l}\text { Interaction } \\
\text { (Variety x Urea } \\
\text { doses) }\end{array}$ & $\begin{array}{l}\text { Plant } \\
\text { height } \\
(\mathrm{cm})\end{array}$ & $\begin{array}{c}\text { Total tillers } \\
\text { hill }^{-1} \\
\text { (No.) }\end{array}$ & $\begin{array}{l}\text { Effective } \\
\text { tillers } \\
\text { hill }^{-1} \text { (No.) }\end{array}$ & $\begin{array}{c}\text { Total } \\
\text { spikelets } \\
\text { panicle }{ }^{-1} \\
\text { (No.) }\end{array}$ & $\begin{array}{l}\text { Grains } \\
\text { panicle } \\
\text { (No.) }\end{array}$ & $\begin{array}{c}\text { 1000-grains } \\
\text { weight } \\
\text { (g) }\end{array}$ & $\begin{array}{l}\text { Grain } \\
\text { yield } \\
\left(\mathrm{t} \mathrm{ha}^{-1}\right)\end{array}$ & $\begin{array}{l}\text { Straw } \\
\text { yield } \\
\left(\mathrm{t} \mathrm{ha}^{-1}\right)\end{array}$ & $\begin{array}{c}\text { Harvest } \\
\text { index } \\
(\%)\end{array}$ \\
\hline $\mathrm{V}_{1} \times \mathrm{U}_{0}$ & 109.9 & $13.02 \mathrm{e}$ & $10.48 f$ & $162.1 \mathrm{i}$ & $145.0 \mathrm{i}$ & 24.17 & $5.92 \mathrm{i}$ & $6.81 \mathrm{~h}$ & $46.50 \mathrm{ab}$ \\
\hline $\mathrm{V}_{1} \times \mathrm{U}_{1}$ & 111.2 & $13.18 \mathrm{e}$ & $10.79 f$ & 164.2hi & 147.6hi & 24.43 & 6.19hi & $7.18 \mathrm{gh}$ & $46.30 \mathrm{~b}$ \\
\hline $\mathrm{V}_{1} \times \mathrm{U}_{2}$ & 113.3 & $14.80 d$ & $12.31 \mathrm{e}$ & 168.2ghi & $152.9 \mathrm{gh}$ & 24.68 & $6.48 \mathrm{gh}$ & $7.26 \mathrm{fgh}$ & 47.16ab \\
\hline $\mathrm{V}_{1} \times \mathrm{U}_{3}$ & 112.3 & $13.28 \mathrm{e}$ & $11.01 \mathrm{f}$ & 169.1fgh & 153.1gh & 24.52 & 6.33ghi & $7.14 \mathrm{gh}$ & $46.99 a b$ \\
\hline $\mathrm{V}_{1} \times \mathrm{U}_{4}$ & 113.1 & $15.96 \mathrm{~b}$ & $13.80 \mathrm{bc}$ & $176.2 \mathrm{cde}$ & 163.1cde & 25.06 & 7.09ef & $8.03 \mathrm{~cd}$ & 46.89ab \\
\hline $\mathrm{V}_{1} \times \mathrm{U}_{5}$ & 113.2 & $14.87 \mathrm{~d}$ & 12.69de & 171.2efg & $155.3 \mathrm{fg}$ & 24.85 & $6.78 \mathrm{fg}$ & 7.73def & $46.77 a b$ \\
\hline $\mathrm{V}_{1} \times \mathrm{U}_{6}$ & 114.1 & $15.20 \mathrm{~cd}$ & $12.30 \mathrm{e}$ & 173.3efg & 158.3efg & 24.85 & $6.82 \mathrm{fg}$ & 7.83de & $46.55 a b$ \\
\hline $\mathrm{V}_{2} \times \mathrm{U}_{0}$ & 94.51 & $14.83 d$ & $12.37 \mathrm{e}$ & $175.5 \mathrm{def}$ & 160.4def & 24.95 & $6.71 \mathrm{fg}$ & 7.45efg & $47.40 \mathrm{ab}$ \\
\hline $\mathrm{V}_{2} \times \mathrm{U}_{1}$ & 97.67 & $15.67 \mathrm{bc}$ & $13.19 \mathrm{~cd}$ & 177.1cde & 162.4de & 24.98 & $7.52 \mathrm{cde}$ & $8.41 \mathrm{bc}$ & $47.21 \mathrm{ab}$ \\
\hline $\mathrm{V}_{2} \times \mathrm{U}_{2}$ & 96.78 & $16.32 \mathrm{ab}$ & $13.93 \mathrm{bc}$ & $182.6 \mathrm{bc}$ & $170.3 b$ & 25.06 & 7.39de & $9.17 a$ & $44.63 c$ \\
\hline $\mathrm{V}_{2} \times \mathrm{U}_{3}$ & 98.52 & $16.12 b$ & $14.09 \mathrm{~b}$ & $182.1 \mathrm{bcd}$ & $166.7 \mathrm{bcd}$ & 25.29 & 7.91abc & $8.87 a b$ & 47.14ab \\
\hline $\mathrm{V}_{2} \times \mathrm{U}_{4}$ & 97.49 & $16.18 \mathrm{~b}$ & $13.97 \mathrm{bc}$ & $184.2 \mathrm{~b}$ & $169.6 b c$ & 25.49 & $7.673 \mathrm{bcd}$ & $8.48 \mathrm{bc}$ & $47.50 \mathrm{a}$ \\
\hline $\mathrm{V}_{2} \times \mathrm{U}_{5}$ & 99.17 & $17.03 a$ & $15.46 a$ & $194.0 \mathrm{a}$ & $184.0 \mathrm{a}$ & 25.76 & $8.38 a$ & $9.26 a$ & $47.51 \mathrm{a}$ \\
\hline $\mathrm{V}_{2} \times \mathrm{U}_{6}$ & 97.43 & $17.00 \mathrm{a}$ & $14.99 a$ & $192.7 \mathrm{a}$ & $181.7 \mathrm{a}$ & 25.69 & $8.11 \mathrm{ab}$ & $9.03 a$ & $47.32 \mathrm{ab}$ \\
\hline LSD $_{0.05}$ & - & 0.685 & 0.741 & 6.13 & 6.50 & - & 0.450 & 0.471 & 1.01 \\
\hline $\begin{array}{l}\text { Level } \\
\text { of sig. }\end{array}$ & NS & $\star \star$ & $\star \star$ & * & $\star \star$ & NS & $* *$ & $\star \star$ & ** \\
\hline CV (\%) & 1.05 & 2.68 & 3.41 & 2.07 & 2.39 & 1.23 & 3.77 & 3.50 & 1.28 \\
\hline
\end{tabular}

In a column, figures having dissimilar letter(s) differ significantly as per DMRT

${ }^{* *}=$ Significant at $1 \%$ level of probability, ${ }^{*}=$ Significant at $5 \%$ level of probability, NS = Not significant

$\mathrm{V}_{1}=$ BINA dhan5 $\quad \mathrm{V}_{2}=$ BRRI dhan29

$\mathrm{U}_{0}=$ Prilled urea $280 \mathrm{~kg} \mathrm{ha}^{-1}$,

$\mathrm{U}_{1}=$ USG $1.8 \mathrm{~g} / 4$ hills of alternate row applied at $5 \mathrm{~cm}$ depth,

$\mathrm{U}_{2}=$ USG $1.8 \mathrm{~g} / 4$ hills of alternate row applied at $10 \mathrm{~cm}$ depth,

$\mathrm{U}_{3}=\mathrm{USG} 2.7 \mathrm{~g} / 4$ hills of alternate row applied at $5 \mathrm{~cm}$ depth,

$U_{4}=$ USG $2.7 \mathrm{~g} / 4$ hills of alternate row applied at $10 \mathrm{~cm}$ depth,

$\mathrm{U}_{5}=$ USG $3.6 \mathrm{~g} / 4$ hills of alternate row applied at $5 \mathrm{~cm}$ depth,

$\mathrm{U}_{6}=\mathrm{USG} 3.6 \mathrm{~g} / 4$ hills of alternate row applied at $10 \mathrm{~cm}$ depth. 
Bony et al.

\section{Conclusion}

According to the result of the experiment, it can be concluded that grain yield of BRRI dhan29 was higher than that of Binadhan-5 in the Boro season. Among the different level of USG with depth of placement, USG 3.6g/4 hills in every alternate row applied at $5 \mathrm{~cm}$ depth of placement showed the best performance. USG level of $3.6 \mathrm{~g} / 4$ hills in every alternate row applied at $5 \mathrm{~cm}$ depth in BRRI dhan29 appeared as the best practice in terms of grain yield in Boro season. Our results suggest that BRRI dhan29 if fertilized with USG $3.6 \mathrm{~g} / 4$ hills in every alternate row at $5 \mathrm{~cm}$ depth would be the best performance in respect of grain yield.

\section{Acknowledgements}

The authors thankfully acknowledge the financial assistance of the BritishCouncil and the Ministry of Science and Technology, Government of the people's Republic of Bangladesh to conduct the research project.

\section{References}

Baligar, A.S. and Ganin, B.A. 2001.Response of rice genotypes to nitrogen level under transplanted condition in Brazil. Newsl. 9 (5): 29-31.

BRRI. (Bangladesh Rice Research Institute) 2000.Annual Report for 1999. Bangladesh Rice Res. Inst., Joydebpur, Gazipur. pp. 338.

BRRI. 2008. Adhunik Dhaner Chas (In Bengali). Bangladesh Rice Research Institute. Joydebpur, Gazipur, Bangladesh. pp. 38-39.

Crassewell, E.T. and De Datta, S.K. 1980. Recent developments in research on nitrogen fertilizers for rice. IRRI Res. Paper Series No. 49: 1-11 and Indian J. Agron. 31(4): 387-389.

Gomez, K.A. and Gomez, A.A. 1984. Statistical Procedures for Agricultural Research. Intl. Rice Res. Inst., John Wiley and Sons. New York, Chichester, Brisbane, Toronto, Singapore. p. 680.

Hasan, S.M. 2007. Effect of level of urea super granules on the performance of Boro rice. M. Sc. Ag. Thesis in Agronomy, BAU, Mymensingh.

Islam, M.S., Paul, S.K. and Sarkar, M.A.R. 2014. Varital performance of modern transplant Aman rice subjected to level of nitrogen application. J. Bangladesh Agril. Univ. 12(1): 55-60

Khisna, K. 2002. An Evaluating of Madagascar System of Rice Production in Aman season with three high potential rice varieties. M.S. Thesis, Dept. Agorn., Bangladesh Agril. Univ., Mymensingh. pp. 36-63.

Nuruzzaman, M., Yamamoto, Y., Nitta, Y., Yoshida, Y. and Miyazaki, A. 2000. Varietal differences in tillering ability of fourteen Japonica and Indica rice varieties. Soil Sci. PlantNutri. 46(2): 381-391.

Pillai, K.G. 1981. Agronomic practices to improve the N use efficiency of rice. Fert. News. 26(2): 3-9.

Rahman, M.A. 2003. Effect of levels of urea super granules and depth of placement on the growth and yield of transplant Aman rice. M.S. Thesis, Dept. Agron., Bangladesh Agril, Univ., Mymensingh. 100 p.

Savant, N.K., Dhane, S.S and talashilkar, S.C. 1991. Fertilizer News. International Fertilizer Development centre, muscle Shoals, Alabama, USA. 36(3): 19-25.

Sharma, S.K. 1985. Present status of intermediate technology in rice production including the possible utilization of blue green algae and azolla, paper presented at the All-India Rice Workshop, held at the Directorate of Rice Research Rajendranagar, Hyderabad during 12-15 April 1985. Indian J. Asril. Sci. 59(3): 154-156. 1989.

Singh, S. and Shivay, Y.S. 2003. Coating of prilled urea with eco-friendly neem (AzadirachoinclicaA. Juss.). ActaAgroninica, Hungarica51(1): 53-59.

Thakur, R.B. 1999. Relative efficiency of prilled urea and modified urea fertilizer in rainfed low land rice. Indian J. Agron. 31(1): 8790.

Tyeb, A., Paul, S.K. and Samad, M.A. 2013.Performance of variety and spacing on the yield and yield contributing characters of transplant Aman rice. J. Agrofor. Environ. 7 (1) : 57-60. 